\title{
Suberoylanilide Hydroxamic Acid as a Potential Therapeutic Agent for Human Breast Cancer Treatment
}

\author{
Lili Huang and Arthur B. Pardee \\ Division of Cancer Biology, Dana-Farber Cancer Institute, and Department \\ of Biological Chemistry and Molecular Pharmacology, Harvard Medical School, \\ Boston, Massachusetts, U.S.A. \\ Communicated by A. Pardee. Accepted June 13, 2000.
}

\begin{abstract}
Background: Suberoylanilide hydroxamic acid (SAHA) is a prototype of the newly developed, second-generation, hybrid polar compounds. It is a novel histone deacetylase inhibitor with high potency for inducing cell differentiation of cultured murine erythroleukemia cells. Studies with SAHA have primarily been performed with hematopoietic tumor cells. Here we extent these studies with SAHA to human breast cancer cell lines in an attempt to find better therapeutic agents for breast cancer treatment.

Materials and Methods: Human breast cancer cell lines, MCF7, MDA-MB-231, and MDA-MB-435, as well as normal cells, including the normal breast epithelial cell line MCF-10A, and fibroblasts, were treated with SAHA. Cells assayed for cell survival by using trypan blue exclusion assay, colony formation assay, and cell cycle and apoptosis analysis. The effects of SAHA on cell cycle and apoptosis regulatory proteins were examined by Western blots analysis. The identification of additional target genes was carried out by differential display (DD) and reverse transcription-polymerase chain reaction (RT-PCR). Results: SAHA inhibited clonogenic growth of MCF7, MDA-MB-231, and MDA-MB-435 breast cancer cells. These cells were more sensitive to SAHAmediated cytotoxic effects than normal breast epithelial cells and fibroblasts. The cytotoxic effects of SAHA on breast cancer cells were manifested by G1
\end{abstract}

and G2/M cell cycle arrest and eventual apoptosis. The pan-caspase inhibitor, Z-VAD.fmk, blocked SAHA-induced cell death, DNA laddering, and cleavage of poly(ADP-ribose) polymerase, indicating the involvement of caspases in SAHA-mediated apoptosis. In addition, SAHA modulated cell cycle and apoptosis regulatory proteins. For example, cyclindependent kinase (CDK) inhibitors p21WAF1/Cipl and p27Kipl were induced, and retinoblastoma protein pRb was hypophosphorylated. Moreover, SAHA induced several genes associated with differentiation and/ or growth inhibition. These genes encode gelsolin, isopentenyl-diphosphate delta isomerase (IDI1), and 1,25-dihydroxyvitamin D-3 up-regulated protein 1 (VDUP1), the last two of which were identified by DD. Induction of these genes may contribute to SAHA-mediated pro-differentiating and antiproliferative effects.

Conclusions: SAHA induced growth inhibition, cell cycle arrest, and eventual apoptosis in human breast cancer cells, possibly by modulating cell cycle and apoptosis regulatory proteins, such as CDK inhibitors p2 1 and p27, pRb, and other differentiation and/or growth inhibition-associated genes, including gelsolin, IDIl and VDUP1. This, together with the low toxicity in normal cells, suggests that SAHA might have therapeutic potential for the treatment of human breast cancers.

\section{Introduction}

Breast cancer is the leading cause of cancer death in women. Current treatments include hormonal therapy with anti-estrogenic compounds for es-

Address correspondence and reprint requests to: Dr. Arthur B. Pardee, Division of Cancer Biology, Dana-Farber Cancer Institute, 44 Binney Street, Boston, MA 02115 , U.S.A. Phone: 617-632-3372; Fax: 617-632-4680; E-mail: pardee@mbcrr.harvard.edu trogen receptor (ER)-positive breast cancers, as well as chemotherapy and the recently developed anti-HER-2/neu therapy with Herceptin for ERnegative breast cancers (1). These are only partially effective and better therapies are needed.

Differentiation therapy using cytodifferentiating agents represents a novel approach for cancer treatment. Retinoic acid-based differentiation therapy has been widely used for 
the treatment of acute promyelocytic leukemia (2), and is currently being evaluated in clinical phase I/II trials in patients with breast cancers (3). Hybrid polar compounds (HPCs) represent another kind of cyto-differentiating agent. Hexamethylene bisacetamide (HMBA), the prototype HPC, is an inducer of terminal differentiation and/or apoptosis in cultured transformed cells, including murine erythroleukemia (MEL) cells, human bladder carcinoma cells, and human myeloma cells (4-6). The effective doses of HMBA are at low millimolar concentrations. Phase II clinical studies indicated high toxic effects, though complete or partial remission was achieved in some patients with myelodysplastic syndrome or acute myelogenous leukemia (7).

To obtain inducers with higher potency and lower toxicity, hydroxamic acid-based, second-generation HPCs have been developed, with effective doses against MEL cells at low micromolar concentrations (4). Suberoylanilide hydroxamic acid (SAHA) is a prototype of the newly developed second-generation HPCs. As with HMBA, SAHA induces terminal differentiation and Gl cell cycle arrest in MEL cells (4). SAHA has also been shown to induce apoptosis in U937 human leukemia cells (8). Moreover, SAHA inhibits the formation of carcinogeninduced tumors in animal models with low toxicity $(9,10)$.

SAHA induces differentiation through a different pathway from HMBA. SAHA, but not HMBA, inhibits histone deacetylase (HDAC) activity (11); whereas, HMBA, but not SAHA, suppresses the expression of the positive Glto S-phase regulator c-myb in MEL cells (4). SAHA is structurally related to another HDAC inhibitor, trichostatin A (TSA), a microbial metabolite originally used as an anti-fungal antibiotic (12). SAHA and TSA inhibit HDACs by directly binding to the enzymes. Most recently, the SAHA and TSA contacting site in Aquifex aeolicus HDAC homologue has been revealed to be an active site consisting of a tubular pocket, a zinc-binding site, and two Asp-His charge-relay systems, which are conserved across the HDAC family (13).

HDACs are a group of enzymes catalyzing deacetylation from lysine residues in the $\mathrm{N}$ terminal tails of core histones. HDACs, together with the opposing enzymes, histone acetyltransferases (HATs), are involved in chromatin remodeling by modifying the acetylation states of histones. HATs mediate transcriptional activation by facilitating the binding of transcription factors to nucleosomal DNA (14); whereas, HDACs mediate transcriptional repression by restricting the access of transcription factors $(15,16)$. In addition, HDACs play important roles in mediating nuclear receptor functions by forming co-repressor complexes with nuclear receptors in the absence of ligands (17). HDACs are also involved in mediating other transcription regulatory pathways by associating with transcription factors, such as the retinoblastoma protein $(p R b)(18,19)$, MaxMad $(20,21)$, etc. Taken together, by modifying chromatin structure and other transcription regulatory proteins, HDACs play important roles in controlling complex biological events, including cell development, differentiation and apoptosis, and thus, are good therapeutic targets for treatment of diseases. A paradigm using HDACs as the therapeutic targets is the successful use of a HDAC inhibitor and differentiating agent, phenylbutyrate, for the treatment of a patient with resistant acute promyelocytic leukemia (PML) (22). PML is caused by the formation of fusion proteins between the retinoic acid receptor- $\alpha$ and the PML protein or the PML zinc finger (PLZF) protein, which recruit HDAC and, thus, block the terminal differentiation of promyelocytic cells (23-25). In this case, combination of phenylbutyrate and retinoic acid resulted in complete remission. Thus, HDAC inhibitors hold promise for cancer treatment.

Such studies mostly have been performed with hematopoietic tumor cells. In this study, we evaluated the effects of SAHA on human breast cancer cell lines, in an attempt to find better therapeutic agents for breast cancer treatment. Our results demonstrated that SAHA induced growth inhibition, cell cycle arrest, and eventual apoptosis in human breast cancer cells with different ER and p53 status. This occurred possibly by modulating cell cycle and apoptosis regulatory proteins, such as cyclin-dependent kinase (CDK) inhibitors p2 1 and p27, pRb, and other differentiation and/or growth inhibition associated genes including gelsolin, isopentenyl-diphosphate-delta isomerase (IDI1), and 1,25-dihydroxyvitamin D-3 up-regulated protein 1 (VDUP1). In addition, the breast cancer cells were more sensitive to SAHA-mediated cytotoxic effects than normal breast epithelial cells and fibroblasts. Taken together, these results suggest that SAHA might have therapeutic 
potential for the treatment of human breast cancers.

\section{Materials and Methods}

Cell Culture

The human breast cancer cell lines, MDA-MB231 and MDA-MB-435, and the normal human breast epithelial cell line, MCF-10A, were obtained from the American Type Culture Collection (Rockville, MD). The human breast cancer cell line, MCF7, kindly was provided by Dr. Beverly Teicher. The normal human dermal fibroblasts from adult skin (NHDF-Ad) were obtained from BioWhittaker, Inc. (Walkersville, MD). Except where indicated, the breast cancer cells were cultured in Dulbecco's modified Eagle's medium (DMEM) supplemented with $10 \%$ fetal bovine serum (FBS), L-glutamine $(2 \mathrm{mM})$, penicillin $(100 \mathrm{U} / \mathrm{ml})$, and streptomycin $(100 \mu \mathrm{g} / \mathrm{ml})$ at $37^{\circ} \mathrm{C}$, in a humidified incubator with $5 \% \mathrm{CO}_{2}$. MCF-10A cells were grown in the same condition for the breast cancer cells, except for the addition of hydrocortisone (2.8 $\mu \mathrm{M})$, insulin $(1 \mu \mathrm{g} / \mathrm{ml})$, and epidermal growth factor EGF $(12.5 \mathrm{ng} / \mathrm{ml})$. In trypan blue exclusion assays, the breast cancer cells were cultured at the same conditions as MCF-10A. The fibroblasts were cultured in fibroblast basal medium (BioWhittaker, Inc.) supplemented with human recombinant fibroblast growth factor $(1 \mathrm{ng} / \mathrm{ml})$, insulin $(5 \mu \mathrm{g} / \mathrm{ml})$, gentamicin $(50 \mu \mathrm{g} / \mathrm{ml})$, and amphotericin-B $(50 \mathrm{ng} / \mathrm{ml})$.

\section{Chemicals}

The hybrid polar compound SAHA was generously provided by Drs. Victoria M. Richon and Paul A. Marks (Memorial Sloan-Kettering Cancer Center) (4). SAHA was dissolved in dimethylsulfoxide (DMSO) at a concentration of $20 \mathrm{mM}$ and stored in small aliquots at $-70^{\circ} \mathrm{C}$. When in use, SAHA was first diluted in medium and then added into the culture. $\mathrm{N}$ benzyloxycarbonyl-Val-Ala-Asp-fluoromethyl ketone (Z-VAD.fmk) was purchased from Calbiochem (San Diego, CA). It was dissolved in DMSO at a concentration of $50 \mathrm{mM}$ and stored at $-20^{\circ} \mathrm{C}$.

\section{Colony Formation Assays}

Cells were seeded into six-well plates at a density of 500 cells per well for MCF7 and MDA-MB-435 cells, and 1000 cells per well for
MDA-MB-231 cells. After overnight incubation, SAHA was added to achieve final concentrations ranging from 0.1 to $4 \mu \mathrm{M}$. Control cells were treated with an equal volume of DMSO. After 2-3 weeks, cells were fixed and stained with Wright-Giemsa Stain (Sigma Chemical Co., St. Louis, MO). Colonies of greater than $\mathbf{5 0}$ cells were enumerated.

\section{Trypan Blue Exclusion Assays}

Cells were seeded into six-well plates at a density of $2 \times 10^{5}$ per well. After overnight incubation, cells were treated with SAHA at final concentrations ranging from 0.5 to $40 \mu \mathrm{M}$. Control cells were treated with an equal volume of DMSO. After $48 \mathrm{hr}$ treatment, cells were harvested, and mixed with $0.4 \%$ trypan blue solution (Sigma). Viable cells that excluded the dye were counted with a hemocytometer.

\section{Cell Cycle and Apoptosis Analysis}

Cells were seeded into $60-\mathrm{mm}$ dishes at a density of $8 \times 10^{5}$ per dish. After overnight incubation, cells were treated with SAHA at a final concentration of $4 \mu \mathrm{M}$ or an equal volume of DMSO. After $24 \mathrm{hr}$ treatment, cells were harvested by trypsinization, and incubated for 30 min at room temperature in staining solution consisting of propidium iodide (PI; $50 \mu \mathrm{g} / \mathrm{ml}$ ), sodium citrate $(0.1 \%)$, Triton X-100 $(0.1 \%)$, and DNase-free RNase $(20 \mu \mathrm{g} / \mathrm{ml})$. Then, stained cells were analyzed for DNA contents by flow cytometry.

\section{DNA Laddering Analysis}

Cells $\left(8 \times 10^{5}\right.$ per dish) were plated into $60-\mathrm{mm}$ dishes. After overnight incubation, cells were treated with SAHA $(4 \mu \mathrm{M})$ or DMSO alone for 24,48 , or $72 \mathrm{hr}$. In some experiments, cells were pretreated with Z-VAD.fmk at $100 \mu \mathrm{M}$ for $1 \mathrm{hr}$ before addition of SAHA. After treatment, cells were harvested by trypsinization and lysed in lysis buffer consisting of $\mathrm{NaCl}$ (100 mM), EDTA (25 mM), Tris-HCl (pH 8; $10 \mathrm{mM}$ ), and sodium dodecyl sulfate (SDS; $0.5 \%)$. Cell lysates were incubated with DNase-free RNase $(250 \mu \mathrm{g} / \mathrm{ml})$ at $37^{\circ} \mathrm{C}$ for $1 \mathrm{hr}$, and further incubated with proteinase $\mathrm{K}$ $(2 \mathrm{mg} / \mathrm{ml})$ for $2 \mathrm{hr}$ to overnight at $50^{\circ} \mathrm{C}$. After addition of loading buffer (10 mM EDTA, $40 \%$ sucrose, and $0.25 \%$ bromophenol blue), samples were loaded into a $2 \%$ agarose gel and resolved by electrophoresis. 


\section{Western Blots Analysis}

Total protein extracts were prepared by lysing cells in extraction buffer consisting of $\mathrm{NaCl}$ (150 mM), Tris-HCl (pH 8; $50 \mathrm{mM}), \mathrm{NP}-40$ $(1 \%)$, sodium deoxycholate $(0.5 \%)$, SDS $(0.1 \%)$, phenylmethylsulfonyl fluoride $(2 \mathrm{mM})$, aprotinin $(1 \mu \mathrm{g} / \mathrm{ml})$, leupeptin $(1 \mu \mathrm{g} / \mathrm{ml})$, and sodium orthovanadate (1 mM). Protein concentrations were determined using the BioRad protein assay reagents (BioRad, Hercules, CA). Total protein extracts (40 $\mu \mathrm{g}$ per lane) were resolved by $12 \%$ SDS polyacrylamide gel electrophoresis (SDS-PAGE) and transferred to nitrocellulose membranes. For detection of poly (ADP-ribose) polymerase (PARP) and pRb, cells were lysed directly in $2 \times$ SDS sample buffer, and the samples were separated on a $10 \%$ SDS-PAGE gel, and then transferred. The membranes were blocked in Tris-buffered saline containing $0.2 \%$ Tween 20 (TBS-T) and $5 \%$ nonfat dried milk, and then probed with various primary antibodies. After washing with TBS-T, blots were further probed with horseradish peroxidase (HRP)-conjugated secondary antibodies. Proteins were detected using the enhanced chemiluminescent protein (ECL) detection system (Amersham Corp., Little Chalfont, England). Each blot subsequently was stripped and reprobed with other antibodies. The following antibodies were used: mouse monoclonal antibodies to Bcl-2 (100), obtained from Santa Cruz Biotechnology (Santa Cruz, CA), pRb (clone G3-245) and PARP (clone 4C10-5), obtained from PharMingen (San Diego, CA), as well as gelsolin (clone GS-2C4) from Sigma; rabbit polyclonal antibodies to p21 (C-19), p27 (C-19) and Bax (P-19) (Santa Cruz); HRPconjugated goat anti-mouse antibody (Cat.\# A9044; Sigma); and goat anti-rabbit antibody (Cat.\# sc-2004; Santa Cruz). All blots were stripped and reprobed with rabbit polyclonal antibody to actin (Cat.\# A-2066; Sigma), which served to normalize the amount of loaded protein.

\section{Differential Display (DD)}

MCF7 cells were treated with DMSO or SAHA at $2 \mu \mathrm{M}$. After $8 \mathrm{hr}$ treatment, total cellular RNA was isolated using TRIzol reagent (Gibco BRL, Grand Island, NY). Contamination of genomic DNA in RNA samples was removed by DNase I treatment using the MessageClean Kit (GenHunter, Nashville, TN). Total RNA $(0.2 \mu \mathrm{g})$ then was primed with one-base-anchored $\mathrm{H}-\mathrm{T}_{11} \mathrm{M}$ primer, $\mathrm{H}-\mathrm{T}_{11} \mathrm{G}$, or $\mathrm{H}-\mathrm{T}_{11} \mathrm{C}$ (from RNAimage kit,
GenHunter), and reverse transcribed into cDNA in a $20-\mu \mathrm{l}$ reaction mixture containing Omniscript reverse transcriptase (Qiagen, Valencia, CA). Following reverse transcription, $2 \mu \mathrm{l}$ cDNA was subjected to polymerase chain reaction (PCR) in a $20-\mu \mathrm{l}$ reaction mixture containing $\alpha$ $\left[{ }^{33} \mathrm{P}\right] \mathrm{dATP}$, AmpliTaq DNA polymerase (PerkinElmer Cetus, Norwalk, CT), the anchor primer $\mathrm{H}-\mathrm{T}_{11} \mathrm{G}$ or $\mathrm{H}-\mathrm{T}_{11} \mathrm{C}$, and the arbitrary primer $\mathrm{H}-$ AP1, H-AP3, H-AP5, H-AP6, or H-AP8 (GenHunter) using a 9600 GeneAmp PCR system (Perkin-Elmer Cetus). Cycling conditions were as follows: 40 cycles of denaturing at $94^{\circ} \mathrm{C}$ for 15 seconds, annealing at $40^{\circ} \mathrm{C}$ for $1 \mathrm{~min}$ and extension at $72^{\circ} \mathrm{C}$ for 30 seconds, followed by a final extension at $72^{\circ} \mathrm{C}$ for $5 \mathrm{~min}$. PCR products were resolved by electrophoresis on an extended-format denaturing $6 \%$ polyacrylamide gel using the programmable GenomyxLR ${ }^{\mathrm{TM}}$ DNA sequencer (Genomyx, Foster City, CA). Differentially expressed bands were excised from the dried gel, and rehydrated in $100 \mu \mathrm{l}$ of $2 \times$ PCR buffer $(20 \mathrm{mM}$ Tris-Cl, pH8.4, $100 \mathrm{mM}$ $\mathrm{KCl}, 3 \mathrm{mM} \mathrm{MgCl}$, and $0.002 \%$ gelatin). DNA was ethanol-precipitated, and reamplified in a $40-\mu \mathrm{l}$ reaction mixture using the same primer set and PCR cycling conditions as used in DD. $8 \mu \mathrm{l}$ of the PCR reaction mixture was resolved in a $\mathbf{2 \%}$ agarose gel to confirm that the isolated DNA was amplified with the correct size. The remaining PCR products were purified using QIAquick PCR purification kit (Qiagen), and then subjected to automatic sequencing with the respective anchor primer, $\mathrm{H}-\mathrm{T}_{11} \mathrm{G}$ or $\mathrm{H}-\mathrm{T}_{11} \mathrm{C}$, by Dana-Farber Molecular Biology Core Facility. DNA sequences were queried against the National Center for Biotechnology Information databases using the BLAST program. http://www.ncbi.nlm.nih.gov/BLAST/ We defined a match as $>95 \%$ identity of bases over a stretch of at least 30 bases.

\section{Reverse Transcription-Polymerase Chain Reaction (RT-PCR)}

Total cellular RNA was isolated and treated with DNase I, as described for DD. $2 \mu \mathrm{g}$ of total RNA was primed with oligo(dT) primer (Gibco BRL), and reverse transcribed into cDNA in a 30- $\mu$ l reaction mixture containing superscript II RT (Gibco BRL). One $\mu$ l of cDNA, which could be undiluted or diluted, depending on the abundance of the specific gene, was subjected to PCR amplification in a 50- $\mu$ l reaction mixture using AmpliTaq DNA 
polymerase and a 9600 GeneAmp PCR system. Cycling conditions were as follows: 30 cycles of denaturing at $94^{\circ} \mathrm{C}$ for $15 \mathrm{sec}$, annealing at $60^{\circ} \mathrm{C}$ for $30 \mathrm{sec}$, and extension at $72^{\circ} \mathrm{C}$ for $1 \mathrm{~min}$, followed by a final extension at $72^{\circ} \mathrm{C}$ for $5 \mathrm{~min}$. The following primers were used: for isopentenyl-diphosphate delta isomerase (IDI1), 5'-AACTAGCAGAGCAAGGTTCA-3' and 5' TAGACAGTGGTCCTCAGTTG-3'; for 1,25dihydroxyvitamin D-3 up-regulated protein 1 (VDUP1), 5'-ACTGGTCTACTGTGTCTCTA-3' and 5'-TCTTCAGCCCACACTTTCTG-3'; for gelsolin, 5'-TGTGATCGAAGAGGTTCCTG 3' and 5'-GACCAGTAATCATCATCCCA-3'. Glyceraldehyde-3-phosphate dehydrogenase (GAPDH) mRNA was also amplified in parallel as a loading control, using primers $5^{\prime}$-ACCACAGTCCATGCCATCAC-3' and ' 5'-TCCACCACCCTGTTGCTGTA-3'. The PCR products were resolved by agarose gel electrophoresis.

\section{Results}

SAHA Inhibited Clonogenic Growth of Human Breast Cancer Cells

As a first step to evaluate the effects of SAHA on human breast cancer cells, we examined the effects of SAHA on clonogenic growth of several breast cancer cell lines with different ER and p53 status. MCF7 cells are ERpositive, and express wild-type p53; whereas,
MDA-MB-231 and MDA-MB-435 cells are ER-negative and express mutant p53. As assessed by colony formation assays, all three cell lines were quite sensitive to SAHA, with an $\mathrm{IC}_{50}$ of approximately $0.4 \mu \mathrm{M}$ (Fig. 1). Growth inhibition of breast cancer cells by SAHA was also verified by 3-[4,5-dimethylthiazol-z-yl]-2,5-diphenyltetrazolium bromide (MTT) assays (data not shown).

\section{Human Breast Cancer Cells Were More Sensitive to} SAHA-mediated Cell Killing Than Were Normal Cells

To investigate if breast cancer cells were more sensitive to SAHA than were normal cells, we compared the effects of SAHA on the breast cancer cell line MCF7 and normal cells, including a normal human breast epithelial cell line MCF-10A and normal human dermal fibroblasts. Cell death analysis using trypan blue exclusion assay showed that MCF7 cells were much more sensitive to SAHA-mediated growth inhibition than MCF-10A and fibroblasts (Fig. 2A). The $\mathrm{IC}_{50}$ of normal cells MCF$10 \mathrm{~A}$ (about $9 \mu \mathrm{M}$ ) and the $\mathrm{IC}_{50}$ of fibroblasts (about $30 \mu \mathrm{M}$ ) were, respectively, about 10and 30-fold higher than that of MCF7 cells (about $0.9 \mu \mathrm{M})$. Microscope examination showed that extensive cell death occurred in MCF7 cells, but not in MCF-10A and fibroblasts, after $48 \mathrm{hr}$ treatment with SAHA at 4 or $10 \mu \mathrm{M}$ (Fig. 2B).

\section{A. MCF7}

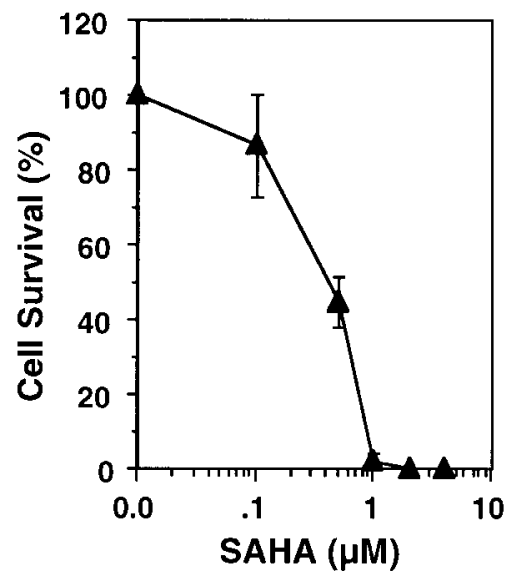

B. MDA-MB-231

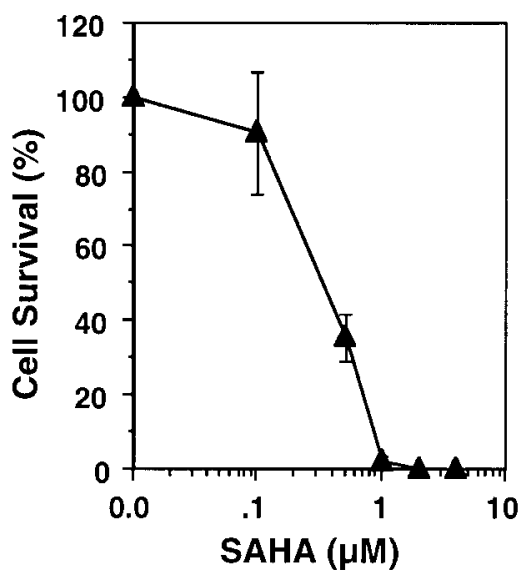

C. MDA-MB-435

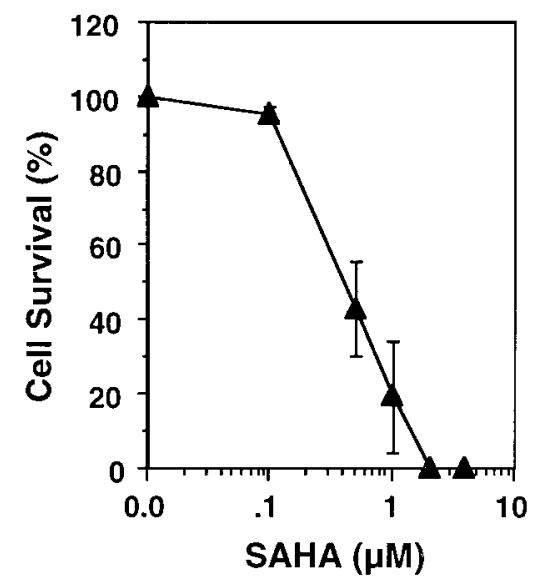

Fig. 1. SAHA inhibits clonogenic growth of human breast cancer cells. (A) MCF7, (B) MDAMB-231, and (C) MDA-MB-435 cells were treated with suberoylanilide hydroxamic acid (SAHA) at concentrations ranging from 0.1 to $4 \mu \mathrm{M}$ for $2-3$ weeks, and then analyzed for cell survival by colony formation assays. The bars represent standard deviations of three independent experiments. 

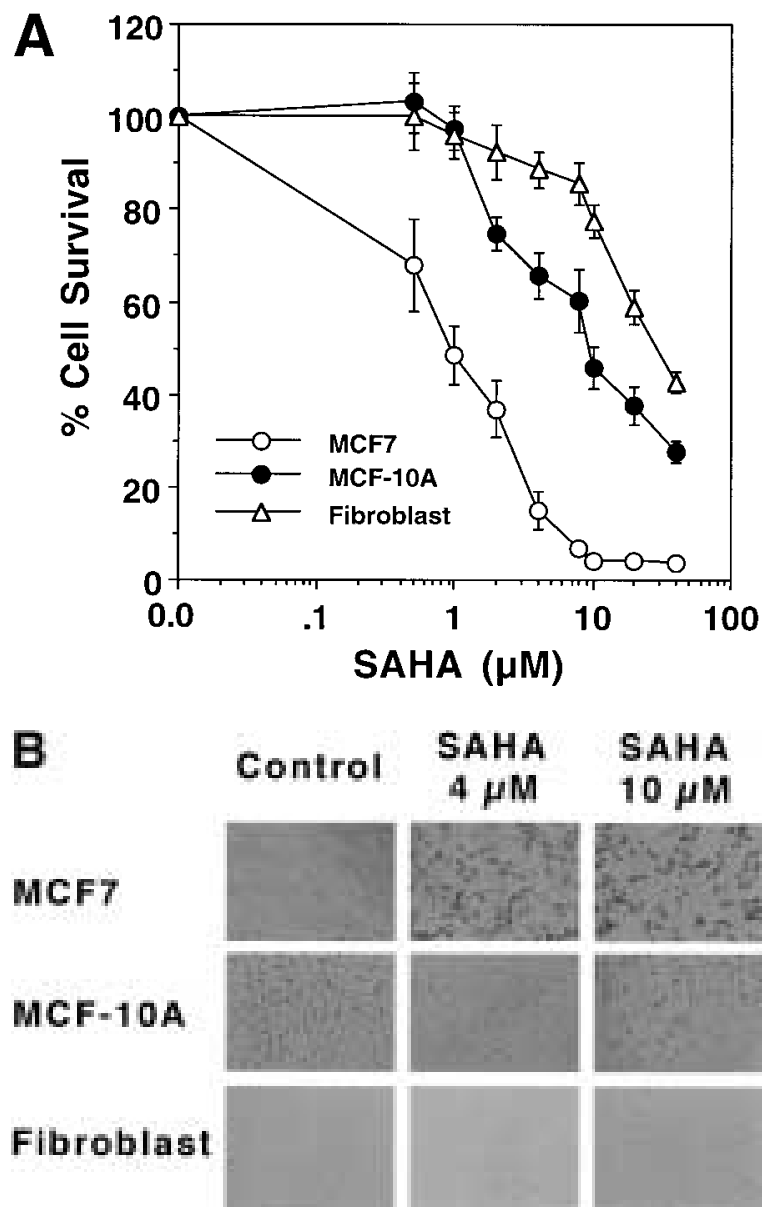

Fig. 2. Human breast cancer cells are more sensitive to SAHA-mediated cell killing than normal cells. (A) Trypan blue exclusion assays of MCF7, MCF-10A, and fibroblast cells that had been treated for $48 \mathrm{hr}$ with suberoylanilide hydroxamic acid (SAHA) at increasing concentrations. The bars represent standard deviations of three independent experiments. (B) Photographic pictures depicting phase-contrast imaging of MCF7, MCF-10A, and fibroblast cells after $48 \mathrm{hr}$ treatment with dimethylsulfoxide (DMSO; control), or SAHA at $4 \mu \mathrm{M}$ or $10 \mu \mathrm{M}$. The MCF7 cells with dark intensity appearing only after SAHA treatment were floating dead cells that increased in number as SAHA concentration increased. No floating dead cells were observed in MCF-10A or fibroblast cells after $48 \mathrm{hr}$ treatment with SAHA at either $4 \mu \mathrm{M}$ or $10 \mu \mathrm{M}$.

\section{SAHA Induced Cell Cycle Arrest in Human Breast Cancer Cells}

SAHA has been shown to induce Gl cell cycle arrest in MEL cells (4). To examine if SAHA also induced $\mathrm{Gl}$ arrest in breast cancer cells, MCF7, MDA-MB-231, and MDA-MB-435 cells were treated with SAHA at $4 \mu \mathrm{M}$ for 24 and $48 \mathrm{hr}$, and then analyzed for cell cycle distribu- tion by flow cytometric analysis (Fig. 3). In MCF7 cells, SAHA induced G1 and G2/M arrest after $24 \mathrm{hr}$ and $48 \mathrm{hr}$ treatment. At $48 \mathrm{hr}$, though the percentage of cells at Gl phase in treated samples was similar or even lower than in controls, there was a blockage at the Gl-S boundary, due to the significant reduction of cells in S phase. In MDA-MB-231 cells, SAHA induced G1 and G2/M arrest at $24 \mathrm{hr}$. However at $48 \mathrm{hr}$, only Gl arrest was induced. In MDAMB-435 cells, SAHA induced both Gl and G2/M phase arrest at $24 \mathrm{hr}$ and $48 \mathrm{hr}$.

Since different doses of the compound may induce different cell cycle arrest, we further determined the cell cycle alteration profiles as a function of increasing doses of SAHA. Cells were treated with SAHA at concentrations ranging from 0.5 to $10 \mu \mathrm{M}$ for 24 and $48 \mathrm{hr}$ and analyzed for cell cycle distributions (Fig. 4). In MCF7 cells, SAHA induced Gl arrest at the growth inhibitory low concentrations $(\leq 2 \mu \mathrm{M})$, and both G1 and G2/M arrest at high concentrations $(>2 \mu \mathrm{M})$, after 24 or $48 \mathrm{hr}$ treatment. The percentage of cells in $\mathrm{G} 2 / \mathrm{M}$ phase increased in a dose-dependent manner. As more cells accumulated at G2/M phase, less cells were at Gl phase. However, the Gl-S boundary was still blocked, as seen by the dramatic reduction in S-phase cells. In MDA-MB-231 cells, at $24 \mathrm{hr}$, SAHA induced Gl and G2/M arrest at concentrations ranging from 1 to 10 $\mu \mathrm{M}$. At $48 \mathrm{hr}$, SAHA induced Gl arrest. No significant $\mathrm{G} 2 / \mathrm{M}$ arrest was induced at this time point. In MDA-MB-435 cells, as in MCF7 cells, SAHA induced Gl arrest at low concentrations $(\leq 2 \mu \mathrm{M})$, and both G1 and G2/M arrest at high concentrations $(>2 \mu \mathrm{M})$ at 24 and $48 \mathrm{hr}$. The percentage of cells in G2/M phase also increased in a dose-dependent manner.

Overall, after 24 or $48 \mathrm{hr}$ treatment, SAHA at $4 \mu \mathrm{M}$ induced a significant reduction of cells in S phase, causing Gl and/or G2/M phase arrest in all cell lines. Depending on cell lines, doses, and time points, cells could be arrested in $\mathrm{Gl}$, or in $\mathrm{Gl}$ and $\mathrm{G} 2 / \mathrm{M}$ phase.

The optimal concentration $(2 \mu \mathrm{M})$ for SAHA used for MEL cells (4) was also effective for breast cancer cells. Treatment of MEL cells with the optimal concentration of SAHA, induces Gl arrest (4). Because in certain cell lines, such as MCF7 and MDA-MB-435 cells, SAHA at low concentrations $(\leq 2 \mu \mathrm{M})$ induced Gl arrest, and at high concentrations $(>2 \mu \mathrm{M})$ induced G1 plus G2/M arrest, MEL cells might 
have additional cell cycle arrest if treated with higher concentrations.

\section{SAHA Induced Apoptosis in Human Breast Cancer Cells}

SAHA caused growth inhibition of breast cancer cells, and significant cell death was observed after $24 \mathrm{hr}$ treatment of MDA-MB-231 cells, after $48 \mathrm{hr}$ treatment of MCF7 cells, and after $72 \mathrm{hr}$ treatment of MDA-MB-435 cells. To determine if SAHA-induced cell death was by apoptosis, we employed propidium iodidestaining and flow cytometric analysis of DNA contents to measure the sub-Gl population, which represented apopototic cells with less than 2N DNA content (Fig. 3). In MCF7 cells, at $24 \mathrm{hr}$ post-treatment, SAHA at $4 \mu \mathrm{M}$ did not induce significant increase in sub-Gl population. However, at $48 \mathrm{hr}$ post-treatment, SAHA induced significant apoptosis $(20.6 \%$, compared with $0.02 \%$ in control). Unlike MCF7 cells, SAHA induced apoptosis earlier in MDAMB-231 cells (19.9\%, compared with $1.7 \%$ in control at $24 \mathrm{hr}$ ). At $48 \mathrm{hr}$, more apoptotic cells were induced $(42.5 \%$, compared with $1.7 \%$ in control). In MDA-MB-435 cells, apoptosis occurred quite slowly. Even at $48 \mathrm{hr}$ post-treatment, only a small percentage of cells went to apoptosis $(9 \%$, compared with $0.2 \%$ in control). However, at later time-points, more MDA-MB-435 cells went to apoptosis (about $15 \%$ at $72 \mathrm{hr}$ and $>20 \%$ at $96 \mathrm{hr}$ after treatment with $4 \mu$ M SAHA; data not shown). We further assessed levels of apoptosis as a function of increasing doses of SAHA (Fig. 4). In all cell lines, as the concentration of SAHA was increased, the percentage of apoptotic cells increased.

SAHA-induced apoptosis in MCF7 and MDA-MB-231 cells was further demonstrated by DNA laddering analysis (Fig. 5). DNA ladders were not detected until $48 \mathrm{hr}$ posttreatment in MCF7 cells, and were detected at $24 \mathrm{hr}$ post-treatment in MDA-MB-231 cells, consistent with the results obtained from measuring the sub-Gl population by flow cytometric analysis of DNA contents.

\section{Inhibition of Caspases Blocks the Apoptotic Effects of SAHA on Human Breast Cancer Cells}

During apoptosis, a cascade of specific cysteine proteases, the caspases, are activated
$(26,27)$. Caspase activation leads to degradation of specific cellular proteins important for DNA repair and structural integrity. One well-known substrate is the DNA repair enzyme, poly(ADP-ribose) polymerase (PARP), which is cleaved proteolytically by activated caspases $(28,29)$. To demonstrate the involvement of caspase activation on the apoptotic effect of SAHA, we examined the effect of the broad-spectrum caspase inhibitor Z-VAD.fmk on SAHA-induced apoptosis in MCF7 and MDA-MB-231 cells. Cells were treated with SAHA $(4 \mu \mathrm{M})$ in the presence or absence of Z-VAD.fmk (100 $\mu \mathrm{M})$, then examined for morphological changes, and analyzed for DNA laddering and PARP cleavage (Fig. 6). After $72 \mathrm{hr}$ treatment, SAHA induced substantial cell death in both cell lines, as characterized by the morphological changes typical of apoptosis and floating dead cell debris in the culture medium. Treatment of cells with Z-VAD.fmk prevented SAHA-induced cell death (Fig. 6A). Consistent with its prevention of SAHA-induced apoptosis, Z-VAD.fmk blo-cked DNA laddering in SAHA-treated MCF7 and MDA-MB-231 cells at $72 \mathrm{hr}$ posttreatment (Fig. 6B). Furthermore, Z-VAD.fmk completely blocked the cleavage of PARP in both cell lines at $24 \mathrm{hr}$ post-treatment (Fig. 6C). Taken together, these results de-monstrated the involvement of caspases in SAHAinduced apoptosis in human breast cancer cells.

SAHA Modulates Cell Cycle and Apoptosis Regulatory Proteins in Human Breast Cancer Cells

In an initial exploration of the molecular mechanisms for SAHA-induced cell cycle alterations and apoptosis, we examined the effects of SAHA on cell cycle and apoptosis regulatory proteins. Whole cell protein extracts were prepared after $24 \mathrm{hr}$ treatment with SAHA $(4 \mu \mathrm{M})$, and analyzed for protein levels by Western blots analysis.

The p53 tumor suppressor is involved in the control of cell cycle checkpoints and apoptosis (30). MCF7 cells express wildtype p53; whereas, MDA-MB-231 and MDAMB-435 cells express mutant p53 (31). As expected, p53 was readily detectable in mutant p53-expressing MDA-MB-231 and -435 cells, but not in wild-type p53-expressing MCF7 cells (Fig. 7A). In MCF7 cells, p53 level was still not observed after SAHA 

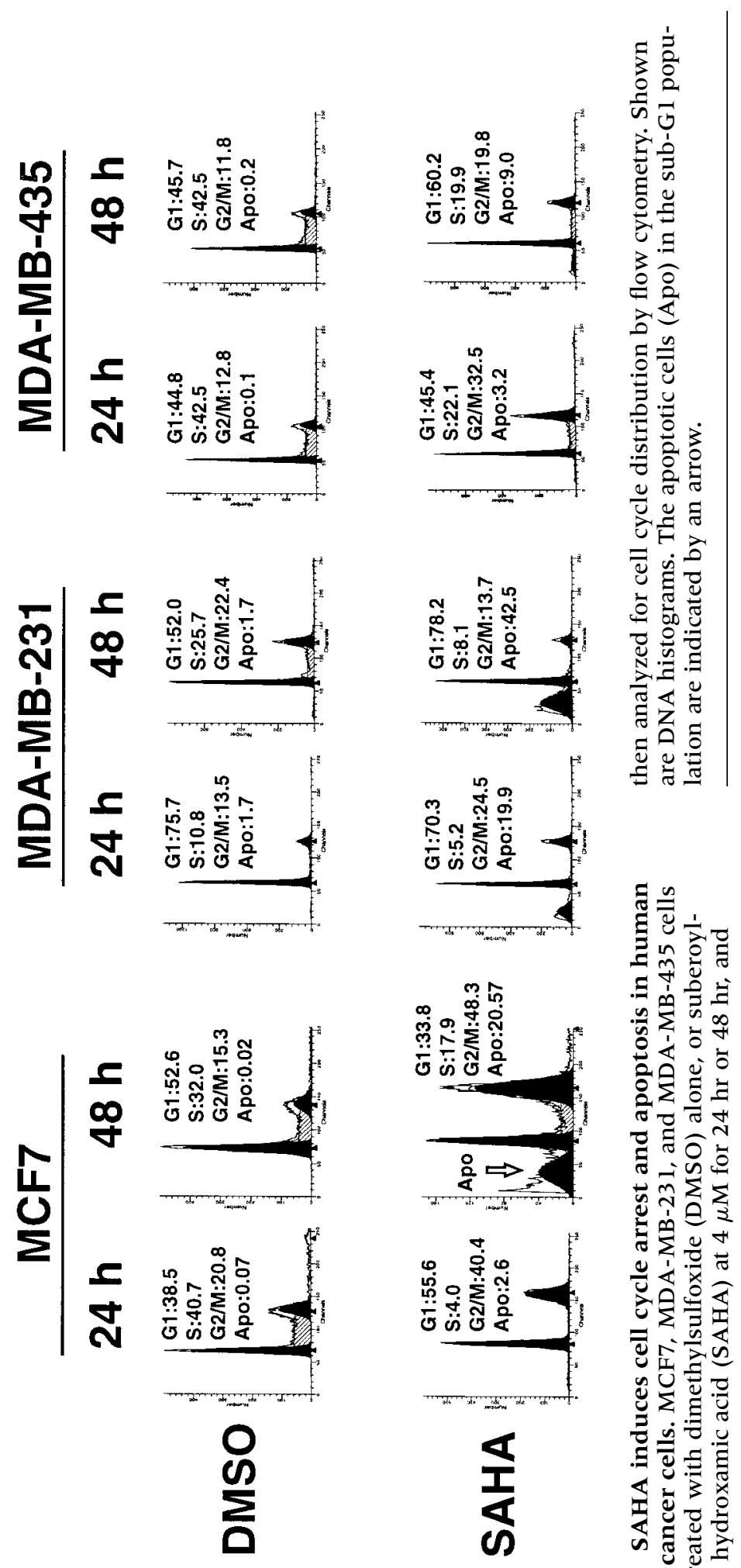

$\Xi$ 卉

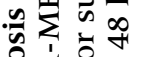

造苍

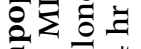

ส ชี

ฮี

$\overline{\mathrm{c}} \tilde{\mathrm{n}} \sum_{i} \sum_{3}$

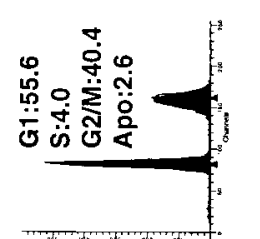

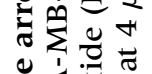

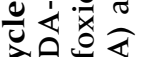

放志 式式岂 巳

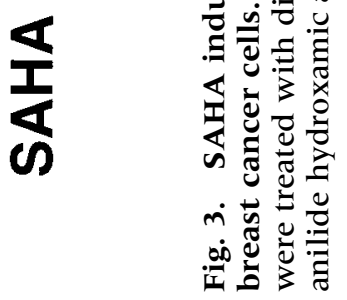


$24 \mathrm{~h}$

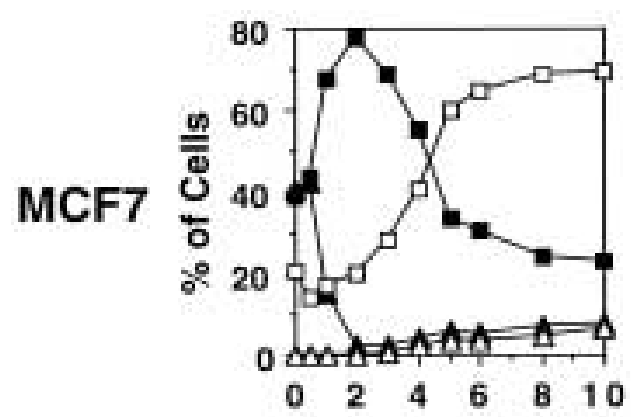

231

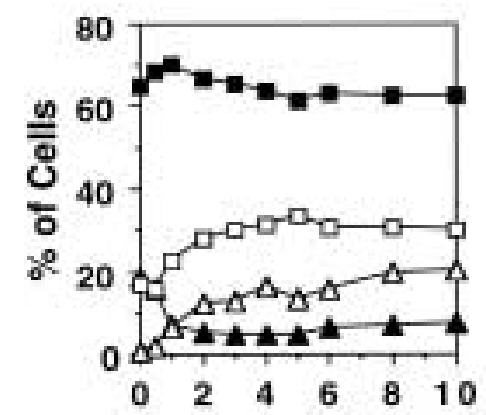

435

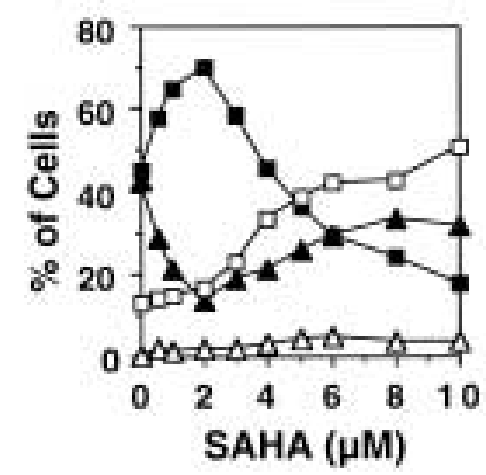

$48 \mathrm{~h}$
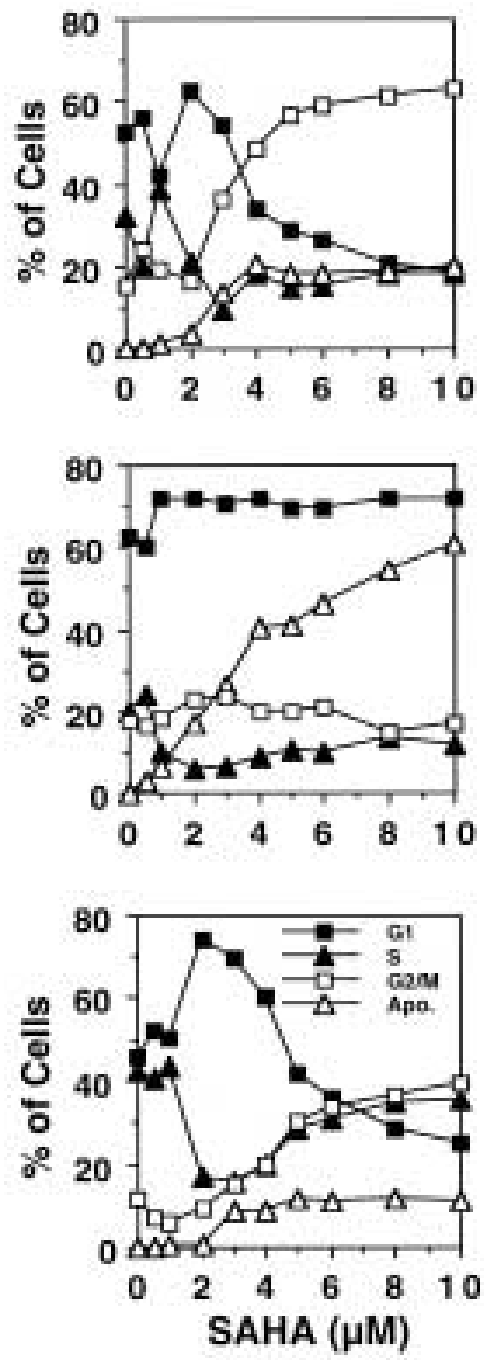

Fig. 4. Dose-dependent effect of SAHA on cell cycle progression in human breast cancer cells. MCF7, MDA-MB-231, and MDA-MB-435 cells were treated with suberoylanilide hydroxamic acid (SAHA) at concentrations ranging from 0.1 to $10 \mu \mathrm{M}$ for $24 \mathrm{hr}$ or $48 \mathrm{hr}$, and then analyzed for cell

treatment. In MDA-MB-231 and -435 cells, mutant p53 was drastically down-regulated by SAHA.

p2 1 and p27 are CDK inhibitors, which are involved in cell cycle regulation and apoptosis (32-35). As shown in Fig. 7A, p27 was greatly induced by SAHA at $24 \mathrm{hr}$ post-treatment in MCF7 and MDA-MB-231 cells, but not in MDAMB-435 cells. However, p21 drastically was induced by SAHA in all three cell lines. Moreover, p2 1 induction was independent of p53, since p21 was induced in both wild-type and mutant p53-expressing cell lines. cycle distribution by flow cytometry. The percentages of cells in sub-G1 (Apo.), G1, S, and G2/M phase are depicted as a function of dose. The percentages of cells distributed in Gl $(\boldsymbol{\square}), \mathbf{S}(\boldsymbol{\Delta})$, and G2/M ( $\square$ ) phases, as well as the percentages of apoptotic cells $(\Delta)$ are shown.

Bcl-2 and its dominant inhibitor, Bax protein, are key regulators of apoptosis $(36,37)$. $\mathrm{Bcl}-2$ promotes cell survival; whereas, Bax promotes cell death. As shown in Fig. 7A, both Bcl-2 and Bax levels were not affected by SAHA at $24 \mathrm{hr}$ post-treatment in all three cell lines, suggesting that SAHA-induced apoptosis is independent of the Bcl-2 and Bax pathway.

We also examined the effect of SAHA on $\mathrm{pRb}$ tumor suppressor, which negatively regulates the progression of cells from Gl to $S$ phase (38). In MCF7 and MDA-MB- 


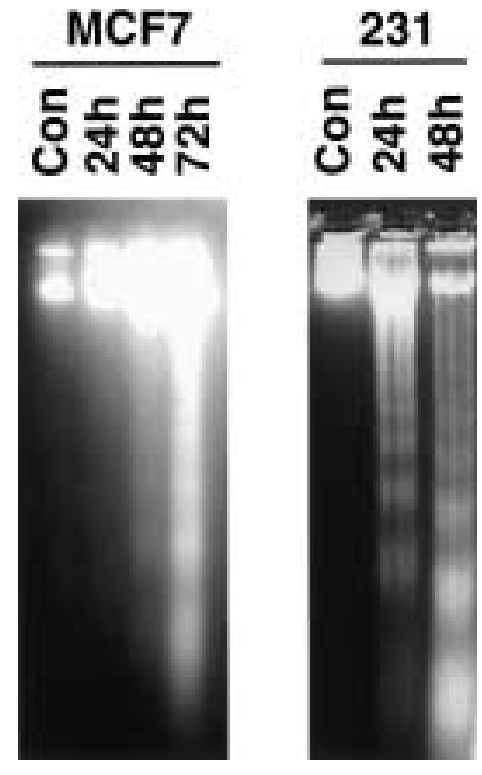

Fig. 5. SAHA induces DNA fragmentation in human breast cancer cells. MCF7 and MDAMB-231 cells were treated with dimethylsulfoxide (DMSO) alone (Con), or suberoylanilide hydroxamic acid (SAHA) at $4 \mu \mathrm{M}$ for $24 \mathrm{hr}, 48 \mathrm{hr}$, or $72 \mathrm{hr}$, and then analyzed for DNA fragmentation by laddering analysis. Shown are photographs of ethidium bromide-stained gels.

231 cells, the majority of $\mathrm{pRb}$ protein was in hypophosphorylated form after SAHA treatment (Fig. 7B). Moreover, the total amount of $\mathrm{pRb}$ was greatly reduced at time points when significant apoptosis occurred, e.g., at $24 \mathrm{hr}$ post-treatment in MDA-MB-23 1 cells, and at $48 \mathrm{hr}$ post-treatment in MCF7 cells, consistent with the anti-apoptotic function of pRb $(39,40)$. In MDA-MB-435 cells, the phosphorylation of $\mathrm{pRb}$ protein was not modulated by SAHA at $24 \mathrm{hr}$ post-treatment.

SAHA Up-regulated Genes Associated with Differentiation and Growth Inhibition in Human Breast Cancer Cells

SAHA was originally developed as a differentiating agent that induced differentiation in MEL cells (4). In the present study, we demonstrated that SAHA exhibited cytotoxic effects on human breast cancer cells by inducing cell cycle arrest and eventual cell death by apoptosis. SAHA initially may induce differentiation of breast cancer cells, and eventually apoptosis. In an attempt to find additional molecular targets associated with differentiation and growth inhibition, we employed DD using RNA prepared from MCF7 cells treated with SAHA $(2 \mu \mathrm{M})$ for a short time $(8 \mathrm{hr})$.

From the isolated DD bands, which were up-regulated by SAHA, we found three DD bands (LH12, LH37, and LH38; Fig. 8A). LH12 matched the human isopentenyl-diphosphate delta isomerase (IDI1) gene (accession \#: NM_004508). Both LH37 and LH38 matched the human gene encoding 1,25-dihydroxyvitamin D-3 up-regulated protein I (VDUPl; accession \#: NM_006472). The differential expression patterns of IDIl and VDUPI were verified by semi-quantitative RT-PCR (Fig. 8B). Treatment with SAHA $(2 \mu \mathrm{M})$ for $8 \mathrm{hr}$ greatly upregulated IDIl (by about 8 -fold) and VDUP1 (by about 5-fold), consistent with the DD patterns.

IDIl is an enzyme catalyzing the isomerization of isopentenyl diphosphate to dimethylallyl diphosphate, which serves as the substrate for the consecutive reaction in the isoprenoid biosynthetic pathway (41). IDIl is induced when the human promyelocytic leukemia cell line HL60 is induced to terminally differentiate with phorbol ester 12-O-tetradecanoyl phorbol-13-acetate (TPA) (42).

VDUP1 is a protein up-regulated by $1,25-$ dihydroxyvitamin D-3 in HL60 cells (43). Recently, VDUPl was found to be identical to the thioredoxin-binding protein-2 (TBP-2), which acted as a negative regulator of thioredoxin (TRX) function and expression (44). TRX is overexpressed in some human tumor cells (45-47) and has cell growth stimulating effects $(48,49)$. Moreover, TRX increases colony formation in soft agarose when transfected into human breast cancer cells; whereas, a dominantnegative mutant TRX inhibits tumor cell growth (50).

To further demonstrate that SAHA induced genes associated with differentiation and growth inhibition, we examined the effect of SAHA on the expression of gelsolin gene, a gene associated with differentiation and growth inhibition, and also a candidate tumor suppressor gene (51). Gelsolin, an actin regulatory protein, has been demonstrated to be down-regulated in various kinds of cancer cells (51-57), and up-regulated in differentiated keratinocytes $(58,59)$ and in cancer cells when induced to differentiate (60). As shown in Fig. 8C, SAHA at 2 

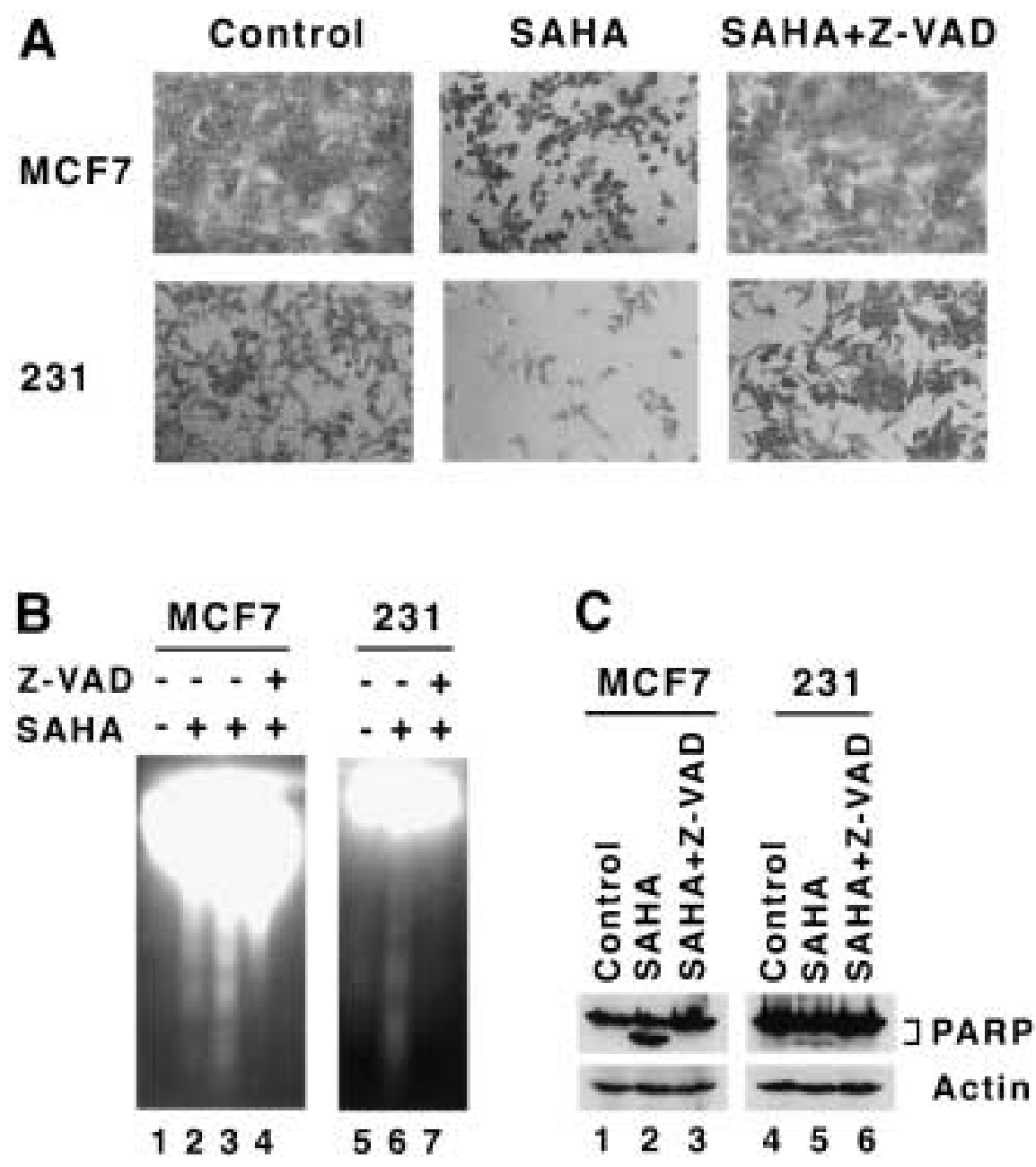

Fig. 6. Caspase inhibitor Z-VAD.fmk blocks SAHA-induced apoptosis in human breast cancer cells. (A) N-benzyloxycarbonyl-Val-AlaAsp-fluoromethyl ketone (Z-VAD.fmk) prevents suberoylanilide hydroxamic acid (SAHA)-induced cell death. MCF7 and MDA-MB-231 cells were treated with dimethylsulfoxide (DMSO) alone (Control), SAHA ( $4 \mu \mathrm{M})$ alone, or SAHA plus Z-VAD (100 $\mu \mathrm{M})$ for $72 \mathrm{hr}$. Z-VAD.fmk was added $\mathrm{l} \mathrm{hr}$ before SAHA. Following treatment, cells were washed with phosphate buffered saline (PBS) after removal of the medium, then fixed and stained with Wright-Giemsa Stain, and examined by microscopy. (B) Z-VAD.fmk prevents SAHA-induced DNA fragmentation. MCF7 and MDA-MB-231 cells were treated with DMSO alone, SAHA $(4 \mu \mathrm{M})$

$\mu \mathrm{M}$ drastically induced the expression of gelsolin gene by about 21-fold in MCF7 cells after $8 \mathrm{hr}$ treatment. Western blots analysis showed that gelsolin protein was also induced and the induction occurred as early as $2 \mathrm{hr}$ post-treatment (data not shown).

alone, or SAHA plus Z-VAD.fmk (100 $\mu \mathrm{M})$. Except for the sample in lane 2 , which was treated for 48 hr, samples from all other lanes were treated for 72 hr. After treatment, cells were analyzed for DNA fragmentation by laddering analysis. (C) Z-VAD. fmk prevents SAHA-induced poly(ADPribose)polymerase (PARP) cleavage. MCF7 and MDA-MB-23 I cells were treated with DMSO alone (Control), SAHA ( $4 \mu \mathrm{M})$ alone, or SAHA plus Z-VAD.fmk (100 $\mu \mathrm{M})$ for $24 \mathrm{hr}$. Cell lysates were analyzed for PARP expression by Western blots analysis. Shown are two PARP signals: the 116 $\mathrm{kDa}$ full-length protein, and the $86 \mathrm{kDa}$ large cleavage product. The same blot was probed with actin as a loading control.

\section{Discussion}

In this study, we report that the hydroxamic acid-based hybrid polar compound, SAHA, a potent inducer of terminal differentiation and/or apoptosis in hematopoietic tumor cells, induced cytotoxic effects on human breast cancer cells. It has significantly lower toxicity in 

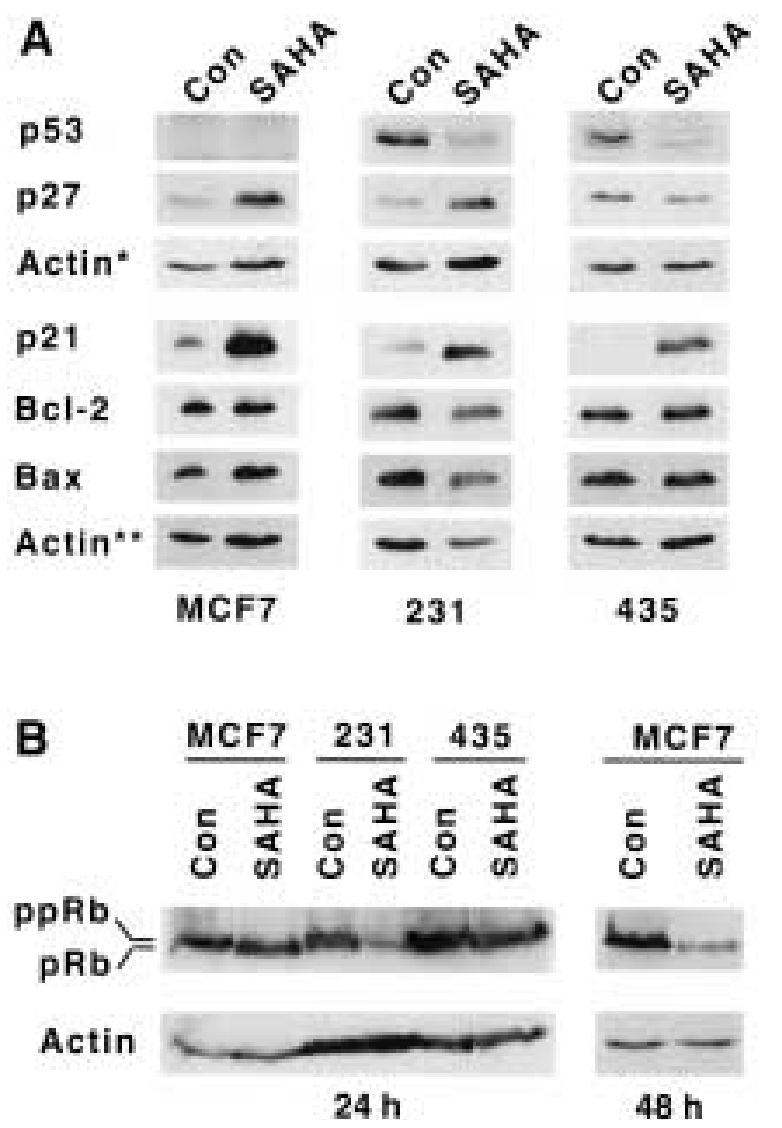

Fig. 7. SAHA modulates cell cycle and apoptosis regulatory proteins in human breast cancer cells. MCF7, MDA-MB-231, and MDAMB-435 cells were treated with dimethylsulfoxide (DMSO) alone (Con), or suberoylanilide hydroxamic acid (SAHA) at $4 \mu \mathrm{M}$ for $24 \mathrm{hr}$ or $48 \mathrm{hr}$, and then analyzed for protein expression of p53, p27, p21, Bcl-2, and Bax (A), as well as retinoblastoma protein (pRb). (B) by Western blots analysis. Cells in the right panel of Fig. B were treated for $48 \mathrm{hr}$; whereas, cells from all other panels were treated for $24 \mathrm{hr}$. The same blots were probed with actin as loading controls. Actin*: loading control for p53 and p27; Actin**: loading control for p2 1, Bcl-2, and Bax; Actin: loading control for $\mathrm{pRb}$.

normal cells, including normal breast epithelial cells and fibroblasts. The selectivity of SAHA on breast tumor cells over normal cells could potentially minimize the side effects of this compound when used for breast cancer treatment. In fact, a recent study with a rat tumor model demonstrated that SAHA inhibited the development of $\mathrm{N}$-methylnitrosourea-induced mammary tumorigenesis without unfavorable side effects (9). Like SAHA, another hydroxamate, azelaic bishydroxamate (ABHA), recently was shown to be selectively toxic to tumor cells without killing normal cells (61). Both these

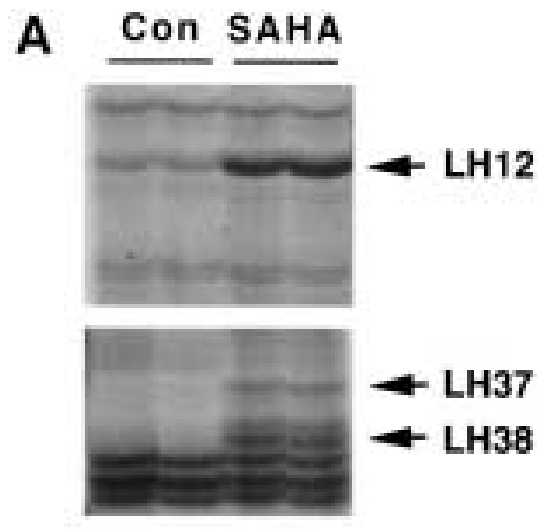

B
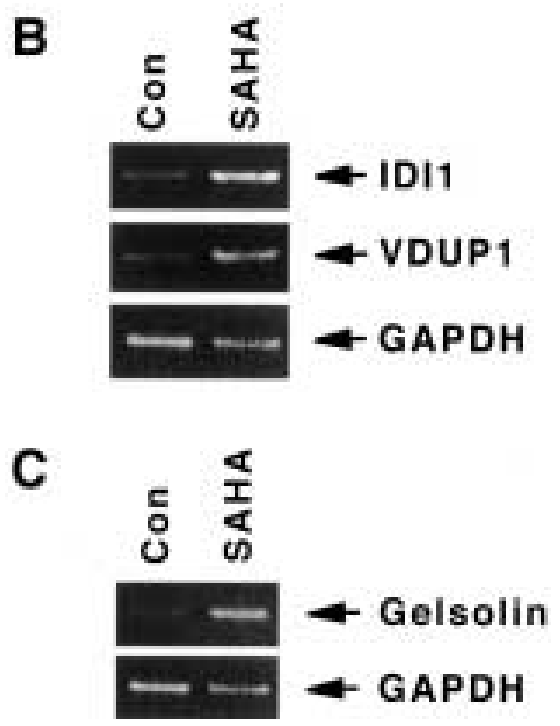

Fig. 8. SAHA up-regulates genes associated with differentiation and/or growth inhibition in human breast cancer cells. (A) Identification of differentially expressed gene by differential display (DD). Total RNA was isolated from MCF7 cells treated with dimethylsulfoxide (DMSO) as control (Con), or suberoylanilide hydroxamic acid (SAHA) at $2 \mu \mathrm{M}$ for $8 \mathrm{hr}$, and then subjected to DD as described in "Materials and Methods." LH12, LH37, and LH38 are up-regulated bands observed in a DD gel. (B) Semi-quantitative reverse transcription-polymerase chain reaction (RT-PCR) of mRNAs from genes matched by LH12

(isopentenyl-diphosphate delta isomerase; IDI1), and LH37/LH38 (1,25-dihydroxyvitamin D-3 up-regulated protein 1; VDUP1). Total RNA isolated from MCF7 cells treated with DMSO (Con), or SAHA at $2 \mu \mathrm{M}$ for $8 \mathrm{hr}$, was reverse transcribed and subjected to PCR amplifications with specific primers. RT-PCR of glyceraldehyde-3-phosphate dehydrogenase (GAPDH) mRNA was included and served as a loading control. Shown are the amplified PCR products (413 bp for IDI 1, $420 \mathrm{bp}$ for VDUP1, and $450 \mathrm{bp}$ for GAPDH). (C) SAHA induces gelsolin gene expression in MCF7 cells. Semi-quantitative RT-PCR of gelsolin mRNA was carried out essentially the same as described above. The amplified PCR product for gelsolin is $270 \mathrm{bp}$. 
hydroxamic acid-based compounds are HDAC inhibitors $(61,62)$, and exhibit anti-tumor activity in vivo with low toxicity $(9,61)$. However, TSA, another hydroxamate and HDAC inhibitor with potent in vitro anti-tumor activity, becomes inactivated and loses anti-tumor activity in vivo (61). Thus, our in vitro data, together with in vivo studies with the rat mammary tumor model (9), suggest that SAHA holds promise for breast cancer treatment.

SAHA-mediated cytotoxic effects on human breast cancer cells were manifested by induction of cell cycle arrest and eventual apoptosis. Depending on dose, time of treatment, and cell line, cells can be arrested in Gl, or in Gl and G2/M phase. Hypoploidy, DNA laddering, and PARP cleavage indicated that SAHA-induced cell death is through an apoptotic mechanism. The three breast cancer cell lines tested showed different apoptotic responses to SAHA treatment. MDA-MB-231 cells showed significant apoptosis after $24 \mathrm{hr}$ treatment; whereas, MCF7 cells required $48 \mathrm{hr}$, and MDA-MB-435 cells required even longer treatment $(>72 \mathrm{hr}$ ) to show significant apoptosis.

The broad-spectrum caspase inhibitor, ZVAD.fmk, prevented SAHA-induced apoptosis, DNA fragmentation, and PARP cleavage, suggesting that SAHA-induced apoptosis is mediated by caspases. Caspases are key mediators of apoptosis $(26,27,63)$. Among the ten distinct caspases, caspase-3, thought to be the executioner most downstream in the apoptotic pathway, is frequently activated by many death signals, and cleaves a wide range of cellular proteins with important functions $(63,64)$. Moreover, it is reported that caspase- 3 is essential for DNA fragmentation and some of the morphological changes associated with apoptosis, though it is dispensable for tumor necrosis factor (TNF)- or staurosporine-induced death (65). Transfection of caspase-3 cDNA into MCF7 cells, which lack caspase- 3 expression due to a 47-bp deletion within the gene (65), restored the DNA laddering and morphological changes, such as shrinkage and blebbing typical of cells undergoing apoptosis (65). In our study, however, we demonstrated that the MCF7 cells also lacked caspase- 3 expression, as measured by Western blots analysis (data not shown), yet exhibited DNA laddering and typical morphological changes associated with apoptosis after SAHA treatment. This indicated that caspase- 3 was not essential for SAHA-induced apoptosis in these MCF7 cells. Our results, together with others $(65,66)$, indicate that whether or not caspase- 3 is essential for apoptotic chromatin condensation and DNA fragmentation is cell- and stimulus-dependent. This is further supported by a recent report showing strainspecific differences in DNA laddering formation in MCF7 cells (67). Among seven MCF7 strains tested, four undergo DNA fragmentation after doxorubicin treatment, whereas three do not.

Since caspase- 3 is not required for SAHAinduced apoptosis, other caspases are involved in the execution of SAHA-induced apoptosis in MCF7 cells. Two other caspases, caspase- 6 and -7 , are also implicated as the executioners of apoptosis $(27,63)$. Caspase- 6 has been shown to be responsible for the cleavage of lamins (68). Caspase-7, a close relative of caspase-3, has been shown to be activated concommitant with PARP cleavage in caspase-3-deficient MCF7 cells, following staurosporine treatment (69). Moreover, caspase-3 and -7 are most likely to be responsible for the in vivo cleavage of PARP $(27,63)$. Thus, in our MCF7 cells, caspase-7 is most likely to be involved in the execution of SAHA-induced apoptosis. In MDA-MB-231 cells, which express caspase-3, as measured by Western blots analysis (data not shown), this might be one of the caspases involved in the execution of SAHA-induced apoptosis.

SAHA-induced cell cycle arrest and apoptosis appears to be through a p53-independent pathway, since both wild-type p53- and mutant p53-expressing cell lines were responsive to SAHA treatment. The wild-type p53 level was not altered in MCF7 cells. However, the mutant p53 dramatically was down-regulated in MDAMB-231 and -435 cells. Since mutant p53 can be oncogenic (70), and enhance genetic instability (71), such strong down-regulation of mutant p53 may play an important role in SAHAmediated anti-proliferative effects. Because inactivation of p53 by mutations has been shown to reduce both radio- and chemosensitivity $(31,72,73)$, agents such as SAHA, which can induce cancer cell death independent of p53 status, could be useful in cancer treatment.

SAHA also modulated other cell cycle and apoptosis regulatory proteins, such as tumor suppressor $\mathrm{pRb}$, and CDK inhibitors $\mathrm{p} 2 \mathrm{l}$ and p27. Modulation of pRb, including total hypophosphorylation and down-regulation at time points when significant apoptosis oc- 
curred, and induction of p27 appeared to be cell type-dependent, since such regulations occurred in MCF7 and MDA-MB-231 cells, but not in MDA-MB-435 cells. p21, however, was induced drastically by SAHA in all three cell lines, in a p53-independent manner. Such marked p21 induction has been observed with other HDAC inhibitors, such as butyrate $(74,75)$, TSA $(76)$, and trapoxin (77), and implicated in modulating HDAC inhibitor-mediated growth inhibition of human cancer cells (75).

Using DD, we identified additional molecular targets associated with differentiation and/or growth inhibition. The two induced genes are IDIl and VDUP1, both of which are up-regulated when human promyelocytic leukemia cells are induced to differentiate by TPA and 1,25-dihydroxyvitamin D-3, respectively $(42,43)$.

IDIl is an enzyme important for isoprenoid biosynthesis and the prenylation of proteins (41). Post-translational modification by prenylation is important for the function of certain proteins, such as the ras $\mathrm{p} 21 /$ ras p21-like small GTP-binding proteins. Ras proteins have been shown to regulate cell growth, differentiation, and apoptosis (78). For instance, during TPAinduced differentiation of hematopoietic leukemia cell lines, ras p2 1 is activated (79), and ras p21/ras p21-like G proteins are markedly induced (80), suggesting potential roles of ras proteins in cell differentiation.

VDUPl was first reported as a novel protein up-regulated by 1,25-dihydroxyvitamin D-3 in HL60 cells (43). Later, the rat VDUP1 homologue was found to be down-regulated in $\mathrm{N}$-methyl-N-nitrosourea (MNU)-induced rat mammary tumors (81), and up-regulated in a cell line derived from MNU-induced rat mammary tumor after treatment with 1,25dihydroxyvitamin D3, which also inhibited cell growth (82). VDUPI recently was found to be identical to the thioredoxin-binding protein-2 (TBP-2), which acts as a negative regulator of thioredoxin (TRX) function and expression (44). TRX is a disulfide oxidoreductase, originally discovered as an adult T-cell leukemia-derived factor from T-lymphotropic virus type I transformed lymphocytes (83). TRX is overexpressed in some human tumor cells (45-47), and has cell growth stimulating effects $(48,49)$. Moreover, TRX increases colony formation in soft agarose when transfected into human breast cancer cells; whereas, a dominantnegative mutant TRX inhibits tumor cell growth
(50). Thus, it is plausible that down-regulation of TRX expression and function by VDUP1 might contribute to the pro-differentiating and antiproliferative effects of 1,25-dihydroxyvitamin D3 observed in promyelocytic leukemia cells and MNU-induced rat mammary tumor cells $(43,82)$, and the antiproliferative and potential pro-differentiating effects of SAHA on human breast cancer cells.

Another differentiation-associated gene, gelsolin, also was induced drastically by SAHA. Gelsolin, an actin-regulatory protein, is down-regulated in a variety of cancer cells (51-57), and up-regulated in differentiated keratinocytes $(58,59)$ and in cancer cells when induced to differentiate (60). Interestingly, as IDIl, gelsolin also is up-regulated in human promyelocytic leukemia HL60 cells when induced to differentiate by phorbol myristate acetate (TPA) (84). As a candidate tumor suppressor, gelsolin, when reintroduced into cancer cells, greatly reduces the colony-forming ability and in vivo tumorigenicity of cancer cells $(51,85)$.

In addition to SAHA, gelsolin can also be up-regulated by other HDAC inhibitors, such as TSA (86); oxamflatin, which is a novel antitumor compound (87); and MS-27-275, a synthetic benzamide derivative with antitumor activity (88). A recent report showed that down-regulation of gelsolin in human breast cancer cells was not due to mutations in the gelsolin genes, but rather to the epigenetic changes in chromatin structure (57). Altered CpG methylation within intron 1 in genomic DNA is found in breast cancer cells, compared with normal, mortal human mammary epithelial cells. Treatment with 5-azacytidine, a DNA methylation inhibitor, moderately up-regulates gelsolin mRNA and protein. Treatment with TSA dramatically up-regulates gelsolin expression (57). As HDAC inhibitors, SAHA may regulate gelsolin expression through a mechanism similar to TSA. Histone acetylation and deacetylation recently was linked to DNA methylation via the methyl-CpG-binding protein MeCP2, which recruited a HDAC-containing co-repressor to methylated DNA sequences $(89,90)$. Inhibition of HDAC and/or DNA methylation, thus, leads to gene activation.

Taken together, IDI1, VDUP1, and gelsolin, all of which are induced in the human promyelocytic leukemia cells when induced to differentiate by differentiating agents, were also induced early in human breast cancer cells by 
SAHA, a potent inducer of terminal differentiation of murine erythroleukemia cells (4). This suggests that SAHA may initially induce differentiation of breast cancer cells, and that induction of these genes may play important roles in SAHA-mediated pro-differentiating and antiproliferative effects on human breast cancer cells.

In summary, our studies demonstrate that SAHA induces cytotoxic effects on human breast cancer cells with significantly lower toxicity on normal cells, including normal breast epithelial cells and fibroblasts. Moreover, SAHA induces cell cycle arrest and eventual apoptosis in human breast cancer cells, possibly by modulating cell cycle and apoptosis regulatory proteins, such as $\mathrm{pRb}$ and CDK inhibitors p21 and p27. Furthermore, SAHA induces several genes associated with differentiation and/or growth inhibition, such as gelsolin, IDIl and VDUP1, which may contribute to SAHA-mediated pro-differentiating and antiproliferative effects. Our in vitro data, together with in vivo studies with the rat mammary tumor model (9), suggest that SAHA might be of therapeutic potential in breast cancer treatment.

\section{Acknowledgments}

We thank Drs. Victoria M. Richon and Paul A. Marks for generously providing (CBHA) and SAHA, and Dr. Heide Ford for critical reading of the manuscript. This work was supported by an NIH grant ROICA61253 (to A.B.P.).

\section{References}

1. Hortobagyi GN. (1998) Drug therapy-treatment of breast cancer. N. Engl. J. Med. 339: 974-984.

2. Holdener EE, Bollag W. (1993) Retinoids. Curr. Opin. Oncol. 5: 1059-1066.

3. Budd GT, Adamson PC, Gupta M, et al. (1998) Phase I/II trial of all-trans retinoic acid and tamoxifen in patients with advanced breast cancer. Clin. Cancer Res. 4: 635-642.

4. Richon VM, Webb Y, Merger R, et al. (1996) Second generation hybrid polar compounds are potent inducers of transformed cell differentiation. Proc. Natl. Acad. Sci. U.S.A. 93: 5705-5708.

5. Richon VM, Russo P, Venta PG, Cordon CC, Rifkind RA, Marks PA. (1997) Two cytodifferentiation agent-induced pathways, differentiation and apoptosis, are distinguished by the expression of human papillomavirus 16 E7 in human bladder carcinoma cells. Cancer Res. 57: 2789-2798.

6. Siegel DS, Zhang X, Feinman R, et al. (1998) Hexamethylene bisacetamide induces programmed cell death (apoptosis) and downregulates BCL-2 expression in human myeloma cells. Proc. Natl. Acad. Sci. U.S.A. 95: 162-166.

7. Andreeff M, Stone R, Michaeli J, et al. (1992) Hexamethylene bisacetamide in myelodysplastic syndrome and acute myelogenous leukemia: a phase II clinical trial with a differentiationinducing agent. Blood 80: 2604-2609.

8. Vrana JA, Decker RH, Johnson CR, et al. (1999) Induction of apoptosis in U937 human leukemia cells by suberoylanilide hydroxamic acid (SAHA) proceeds through pathways that are regulated by $\mathrm{Bcl}-2 / \mathrm{Bcl}-\mathrm{XL}$, c-Jun, and p2 1CIP1, but independent of p53. Oncogene 18: 7016-7025.

9. Cohen LA, Amin S, Marks PA, Rifkind RA, Desai D, Richon VM. (1999) Chemoprevention of carcinogen-induced mammary tumorigenesis by the hybrid polar cytodifferentiation agent, suberanilohydroxamic acid (SAHA). Anticancer Res. 19: 4999-5005.

10. Cohen LA, Amin S, Marks PA, Rifkind RA, Desai D, Richon VM. (1999) Chemoprevention of carcinogen-induced mammary tumorigenesis by the hybrid polar cytodifferentiating agent, suberanilohydroxamic acid (SAHA). Anticancer Res. 19: 4999-5005.

11. Richon VM, Emiliani S, Verdin E, et al. (1998) A class of hybrid polar inducers of transformed cell differentiation inhibits histone deacetylases. Proc. Natl. Acad. Sci. U.S.A. 95: 3003-3007.

12. Yoshida M, Kijima M, Akita M, Beppu T. (1990) Potent and specific inhibition of mammalian histone deacetylase both in vivo and in vitro by trichostatin A. J. Biol. Chem. 265: 17174-17179.

13. Finnin MS, Donigian JR, Cohen A, et al. (1999) Structures of a histone deacetylase homologue bound to the TSA and SAHA inhibitors. Nature 401: 188-193.

14. Struhl K. (1998) Histone acetylation and transcriptional regulatory mechanisms. Genes Dev. 12: 599-606.

15. Wolffe AP. (1997) Transcriptional control. Sinful repression. Nature 387: 16-17.

16. Pazin MJ, Kadonaga JT. (1997) What's up and down with histone deacetylation and transcription? Cell 89: 325-328.

17. Torchia J, Glass C, Rosenfeld MG. (1998) Coactivators and co-repressors in the integration of transcriptional responses. Curr. Opin. Cell Biol. 10: 373-383.

18. Magnaghi JL, Groisman R, Naguibneva I, et al. (1998) Retinoblastoma protein represses transcription by recruiting a histone deacetylase. Nature 391: 601-605. 
19. Brehm A, Miska EA, McCance DJ, Reid JL, Bannister AJ, Kouzarides T. (1998) Retinoblastoma protein recruits histone deacetylase to repress transcription. Nature 391: 597-601.

20. Hassig CA, Fleischer TC, Billin AN, Schreiber SL, Ayer DE. (1997) Histone deacetylase activity is required for full transcriptional repression by mSin3 A. Cell 89: 341-347.

21. Laherty CD, Yang WM, Sun JM, Davie JR, Seto E, Eisenman RN. (1997) Histone deacetylases associated with the mSin 3 corepressor mediate mad transcriptional repression. Cell 89: 349-356.

22. Warrell RP, He LZ, Richon V, Calleja E, Pandolfi PP. (1998) Therapeutic targeting of transcription in acute promyelocytic leukemia by use of an inhibitor of histone deacetylase. J. Natl. Cancer Inst. 90: $1621-1625$.

23. Lin RJ, Nagy L, Inoue S, Shao W, Miller WJ, Evans RM. (1998) Role of the histone deacetylase complex in acute promyelocytic leukaemia. Nature 391: 811-814.

24. Grignani F, De MS, Nervi C, et al. (1998) Fusion proteins of the retinoic acid receptor-alpha recruit histone deacetylase in promyelocytic leukaemia. Nature 391: 815-818.

25. He LZ, Guidez F, Tribioli C, et al. (1998) Distinct interactions of PML-RARalpha and PLZF-RARalpha with co-repressors determine differential responses to RA in APL. Nat. Genet. 18: 126-135.

26. Alnemri ES, Livingston DJ, Nicholson DW, et al. (1996) Human ICE/CED-3 protease nomenclature. Cell 87: 171.

27. Salvesen GS, Dixit VM. (1997) Caspases: intracellular signaling by proteolysis. Cell 91 : $443-446$.

28. Kaufmann SH, Desnoyers S, Ottaviano Y, Davidson NE, Poirier GG. (1993) Specific proteolytic cleavage of poly(ADP-ribose) polymerase: an early marker of chemotherapy-induced apoptosis. Cancer Res. 53: 3976-3985.

29. Lazebnik YA, Kaufmann SH, Desnoyers S, Poirier GG, Earnshaw WC. (1994) Cleavage of poly(ADP-ribose) polymerase by a proteinase with properties like ICE. Nature 371: 346-347.

30. Bates S, Vousden KH. (1996) p53 in signaling checkpoint arrest or apoptosis. Curr. Opin. Genet. Dev. 6: 12-18.

31. O'Connor PM, Jackman J, Bae I, et al. (1997) Characterization of the p53 tumor suppressor pathway in cell lines of the National Cancer Institute anticancer drug screen and correlations with the growth-inhibitory potency of 123 anticancer agents. Cancer Res. 57: 4285-4300.

32. Harper JW, Adami GR, Wei N, Keyomarsi K, Elledge SJ. (1993) The p2l Cdk-interacting protein Cipl is a potent inhibitor of Gl cyclindependent kinases. Cell 75: 805-816.

33. Dulic V, Kaufmann WK, Wilson SJ, et al. (1994) p53-dependent inhibition of cyclin-dependent kinase activities in human fibroblasts during radiation-induced G1 arrest. Cell 76: 1013-1023.
34. Kato JY, Matsuoka M, Polyak K, Massague J, Sherr CJ. (1994) Cyclic AMP-induced Gl phase arrest mediated by an inhibitor (p27Kipl) of cyclin-dependent kinase 4 activation. Cell 79: 487496.

35. Toyoshima H, Hunter T. (1994) p27, a novel inhibitor of Gl cyclin-Cdk protein kinase activity, is related to p21. Cell 78: 67-74.

36. Reed JC. (1994) Bcl-2 and the regulation of programmed cell death. J. Cell Biol. 124: 1-6.

37. Korsmeyer SJ. (1995) Regulators of cell death. Trends Genet. 11: 101-105.

38. Weinberg RA. (1995) The retinoblastoma protein and cell cycle control. Cell 81: 323-330.

39. Almasan A, Yin Y, Kelly RE, et al. (1995) Deficiency of retinoblastoma protein leads to inappropriate S-phase entry, activation of E2Fresponsive genes, and apoptosis. Proc. Natl. Acad. Sci. USA 92: 5436-5440.

40. Janicke RU, Walker PA, Lin XY, Porter AG. (1996) Specific cleavage of the retinoblastoma protein by an ICE-like protease in apoptosis. EMBO J. 15: 6969-6978.

41. Hahn FM, Xuan JW, Chambers AF, Poulter CD. (1996) Human isopentenyl diphosphate: dimethylallyl diphosphate isomerase: overproduction, purification, and characterization. Arch. Biochem. Biophys. 332: 30-34.

42. Xuan JW, Kowalski J, Chambers AF, Denhardt DT. (1994) A human promyelocyte mRNA transiently induced by TPA is homologous to yeast IPP isomerase. Genomics 20: 129-131.

43. Chen KS, DeLuca HF. (1994) Isolation and characterization of a novel cDNA from HL-60 cells treated with 1,25-dihydroxyvitamin D-3. Biochim. Biophys. Acta 1219: 26-32.

44. Nishiyama A, Matsui M, Iwata S, et al. (1999) Identification of thioredoxin-binding protein-2/ vitamin $\mathrm{D}(3)$ up-regulated protein 1 as a negative regulator of thioredoxin function and expression. J. Biol. Chem. 274: 21645-21650.

45. Fujii S, Nanbu Y, Nonogaki H, et al. (1991) Coexpression of adult T-cell leukemia-derived factor, a human thioredoxin homologue, and human papillomavirus DNA in neoplastic cervical squamous epithelium. Cancer 68: 1583- 1591.

46. Nakamura H, Masutani H, Tagaya Y, et al. (1992) Expression and growth-promoting effect of adult T-cell leukemia-derived factor. A human thioredoxin homologue in hepatocellular carcinoma. Cancer 69: 2091-2097.

47. Berggren M, Gallegos A, Gasdaska JR, Gasdaska PY, Warneke J, Powis G. (1996) Thioredoxin and thioredoxin reductase gene expression in human tumors and cell lines, and the effects of serum stimulation and hypoxia. Anticancer Res. 16: 3459-3466.

48. Wakasugi N, Tagaya Y, Wakasugi H, et al. (1990) Adult T-cell leukemia-derived factor/thioredoxin, produced by both human T-lymphotropic 
virus type I- and Epstein-Barr virus-transformed lymphocytes, acts as an autocrine growth factor and synergizes with interleukin 1 and interleukin 2. Proc. Natl. Acad. Sci. U.S.A. 87: 8282- 8286 .

49. Gasdaska JR, Berggren M, Powis G. (1995) Cell growth stimulation by the redox protein thioredoxin occurs by a novel helper mechanism. Cell Growth Differ. 6: 1643-1650.

50. Gallegos A, Gasdaska JR, Taylor CW, et al. (1996) Transfection with human thioredoxin increases cell proliferation and a dominantnegative mutant thioredoxin reverses the transformed phenotype of human breast cancer cells. Cancer Res. 56: 5765-5770.

51. Tanaka M, Mullauer L, Ogiso Y, et al. (1995) Gelsolin: a candidate for suppressor of human bladder cancer. Cancer Res. 55: 3228-3232.

52. Asch HL, Head K, Dong Y, et al. (1996) Widespread loss of gelsolin in breast cancers of humans, mice, and rats. Cancer Res. 56: 4841-4845.

53. Dosaka AH, Hommura F, Fujita H, et al. (1998) Frequent loss of gelsolin expression in non-small cell lung cancers of heavy smokers. Cancer Res. 58: 322-327.

54. Lee HK, Driscoll D, Asch H, Asch B, Zhang PJ. (1999) Downregulated gelsolin expression in hyperplastic and neoplastic lesions of the prostate. Prostate 40: 14-19.

55. Asch HL, Winston JS, Edge SB, Stomper PC, Asch BB. (1999) Down-regulation of gelsolin expression in human breast ductal carcinoma in situ with and without invasion. Breast Cancer Res. Treat. 55: 179-188.

56. Dong Y, Asch HL, Medina D, et al. (1999) Concurrent deregulation of gelsolin and cyclin D 1 in the majority of human and rodent breast cancers. Int. J. Cancer 81: 930-938.

57. Mielnicki LM, Ying AM, Head KL, Asch HL, Asch BB. (1999) Epigenetic regulation of gelsolin expression in human breast cancer cells. Exp. Cell Res. 249: 161-176.

58. Schwartz SB, Higgins PJ, Rajasekaran AK, Staiano CL. (1994) Gelsolin expression in normal human keratinocytes is a function of induced differentiation. Adv. Exp. Med. Biol. 358: 169-181.

59. Olsen E, Rasmussen HH, Celis JE. (1995) Identification of proteins that are abnormally regulated in differentiated cultured human keratinocytes. Electrophoresis 16: 2241-2248.

60. Dieffenbach CW, SenGupta DN, Krause D, Sawzak D, Silverman RH. (1989) Cloning of murine gelsolin and its regulation during differentiation of embryonal carcinoma cells. J. Biol. Chem. 264: 13281-13288.

61. Qiu L, Kelso MJ, Hansen C, West ML, Fairlie DP, Parsons PG. (1999) Anti-tumour activity in vitro and in vivo of selective differentiating agents containing hydroxamate. Br. J. Cancer 80: 1252-1258.
62. Richon VM, Rifkind RA, Marks PA. (1992) Expression and phosphorylation of the retinoblastoma protein during induced differentiation of murine erythroleukemia cells. Cell Growth Differ. 3: $413-420$.

63. Nicholson DW, Thornberry NA. (1997) Caspases: killer proteases. Trends Biochem. Sci. 22: 299-306.

64. Porter AG, Janicke RU. (1999) Emerging roles of caspase-3 in apoptosis. Cell Death Differ. 6: 99-04.

65. Janicke RU, Sprengart ML, Wati MR, Porter AG. (1998) Caspase-3 is required for DNA fragmentation and morphological changes associated with apoptosis. J. Biol. Chem. 273: 9357-9360.

66. Woo M, Hakem R, Soengas MS, et al. (1998) Essential contribution of caspase 3/CPP32 to apoptosis and its associated nuclear changes. Genes Dev. 12: 806-819.

67. Gooch JL, Yee D. (1999) Strain-specific differences in formation of apoptotic DNA ladders in MCF-7 breast cancer cells. Cancer Lett. 144: 31-37.

68. Orth K, Chinnaiyan AM, Garg M, Froelich CJ, Dixit VM. (1996) The CED-3/ICE-like protease Mch2 is activated during apoptosis and cleaves the death substrate lamin A. J. Biol. Chem. 271: 16443-16446.

69. Germain M, Affar EB, D'Amours D, Dixit VM, Salvesen GS, Poirier GG. (1999) Cleavage of automodified poly(ADP-ribose) polymerase during apoptosis-Evidence for involvement of caspase-7. J. Biol. Chem. 274: 28379-28384.

70. Dittmer D, Pati S, Zambetti G, et al. (1993) Gain of function mutations in p53. Nat. Genet. 4: 42-46.

71. Liu PK, Kraus E, Wu TA, Strong LC, Tainsky MA. (1996) Analysis of genomic instability in Li-Fraumeni fibroblasts with germline p53 mutations. Oncogene 12: 2267-2278.

72. Lowe SW, Bodis S, McClatchey A, et al. (1994) p53 status and the efficacy of cancer therapy in vivo. Science 266: 807-810.

73. Lowe SW. (1995) Cancer therapy and p53. Curr. Opin. Oncol. 7: 547-553.

74. Nakano K, Mizuno T, Sowa Y, et al. (1997) Butyrate activates the WAFl/Cipl gene promoter through $\mathrm{Spl}$ sites in a p53-negative human colon cancer cell line. J. Biol. Chem. 272: 22 199-22206.

75. Archer SY, Meng S, Shei A, Hodin RA. (1998) p21(WAF1) is required for butyrate-mediated growth inhibition of human colon cancer cells. Proc.Natl. Acad. Sci. U.S.A. 95: 6791-6796.

76. Sowa Y, Orita T, Minamikawa S, et al. (1997) Histone deacetylase inhibitor activates the WAFl/Cipl gene promoter through the $\mathrm{Spl}$ sites. Biochem. Biophy. Res. Commun. 241: 142-150.

77. Sambucetti LC, Fischer DD, Zabludoff S, et al. (1999) Histone deacetylase inhibition selectively alters the activity and expression of cell cycle proteins leading to specific chromatin acetylation and antiproliferative effects. J. Biol. Chem. 274: 34940-34947. 
78. Olson MF, Marais R. (2000) Ras protein signalling. Semin. Immunol. 12: 63-73.

79. Katagiri K, Hattori S, Nakamura S, Yamamoto T, Yoshida T, Katagiri T. (1994) Activation of Ras and formation of GAP complex during TPAinduced monocytic differentiation of HL-60 cells. Blood 84: 1780-1789.

80. Adachi M, Ryo R, Yoshida A, et al. (1992) Induction of smg p21/raplA p21/krev-1 p21 gene expression during phorbol ester-induced differentiation of a human megakaryocytic leukemia cell line. Oncogene 7: 323-329.

81. Young LH, Yang X, Voigt JM. (1996) Alteration of gene expression in rat mammary tumors induced by N-methyl-N-nitrosourea. Mol. Carcinog. 15: 251-260.

82. Yang X, Young LH, Voigt JM. (1998) Expression of a vitamin D-regulated gene (VDUP-1) in untreated- and MNU-treated rat mammary tissue. Breast Cancer Res. Treat. 48: 33-44.

83. Tagaya Y, Maeda Y, Mitsui A, et al. (1989) ATL-derived factor (ADF), an IL-2 receptor/ Tac inducer homologous to thioredoxin; possible involvement of dithiol-reduction in the IL-2 receptor induction. EMBO J. 8: 757764.

84. Kwiatkowski DJ. (1988) Predominant induction of gelsolin and actin-binding protein during myeloid differentiation. J. Biol. Chem. 263: $13857-$ 13862.

85. Tanaka M, Sazawa A, Shinohara N, et al. (1999) Gelsolin gene therapy by retrovirus producer cells for human bladder cancer in nude mice. Cancer Gene Ther. 6: 482-487.

86. Hoshikawa Y, Kwon HJ, Yoshida M, Horinouchi S, Beppu T. (1994) Trichostatin A induces morphological changes and gelsolin expression by inhibiting histone deacetylase in human carcinoma cell lines. Exp. Cell Res. 214: 189-197.

87. Kim YB, Lee KH, Sugita K, Yoshida M, Horinouchi S. (1999) Oxamflatin is a novel antitumor compound that inhibits mammalian histone deacetylase. Oncogene 18: 2461-2470.

88. Saito A, Yamashita T, Mariko Y, et al. (1999) A synthetic inhibitor of histone deacetylase, MS27-275, with marked in vivo antitumor activity against human tumors. Proc. Natl. Acad. Sci. U.S.A. 96: 4592-4597.

89. Nan X, Ng HH, Johnson CA, et al. (1998) Transcriptional repression by the methyl-CpG-binding protein MeCP2 involves a histone deacetylase complex. Nature 393: 386-389.

90. Jones PL, Veenstra GJ, Wade PA, et al. (1998) Methylated DNA and MeCP2 recruit histone deacetylase to repress transcription. Nat. Genet. 19: 187-191. 